\title{
The Relationship Between Serum Vaspin Levels and the Degree of Coronary Involvement in Patients with Stable Angina Pectoris
}

\section{Stabil Angina Pektorisli Hastalarda Serum Vaspin Düzeyleri ile Damar Tutulum Derecesi Arasindaki Ilişki}

\author{
๑ Ilter Bozacı, ๑ Oktay Özkan*, ๑ Alev Arat Özkan**, ๑ Macit Koldaş***, ๑ Savaş Öztürk* \\ Bozyaka Training and Research Hospital, Clinic of Nephrology, Izmir, Turkey \\ *University of Health Sciences Turkey, Haseki Taining and Research Hospital, Clinic of Nephrology, Istanbul, Turkey \\ **istanbul University Institute of Cardiology, Department of Cardiology, Istanbul, Turkey \\ ***University of Health Sciences Turkey, Haseki Training and Research Hospital, Clinic of Biochemistry, Istanbul, Turkey
}

\section{Abstract}

\begin{abstract}
Aim: Vaspin is an insulin-sensitive adipokine secreted from visceral fat tissue, and belongs to the serine protease inhibitor family. The relationship between vaspin level and coronary artery disease is not known yet. We aimed to investigate the relationship between serum vaspin levels and degree of vessel involvement in coronary angiography in patients with stable angina pectoris.
\end{abstract}

Methods: The patients were chosen from those who had coronary angiography with the diagnosis of stable angina pectoris. Patients with previously diagnosed chronic heart disease, chronic liver disease, renal failure, thyroid dysfunction and any systemic infectious or malignant disease, patients receiving immunosupressive treatment and those who did not give informed consent were excluded from the study. Serum vaspin measurements were performed using an East Biopharm enzyme-linked immunoassay (ELISA) kit using the sandwich ELISA method. For determination of the severity of coronary lesions, the modified Gensini score was used.

Results: Eighty-eight patients [34 female (38.6\%) and 54 male $(91.4 \%)]$ were included in the study. Vaspin levels were similar in male $(1.17 \pm 1.54 \mathrm{ng} / \mathrm{L})$ and female $(1.09 \pm 1.23 \mathrm{ng} / \mathrm{L})$ patients $(p=0.46)$. There was no correlation between vaspin levels and the number of vessels involved $(p=0.75)$. Vaspin levels were similar in diabetic and nondiabetic patients.

Conclusion: Vaspin may not be a sensitive marker of the degree of vascular lesions in patients with stable angina pectoris. The underlying cause is probably lack of significant changes in inflammatory cascade and oxidative stress in the involved group of patients.
Öz
Amaç: Vaspin, serin proteaz ailesinden, insulin duyarlı bir adipokin olup visseral yağ dokudan salınmaktadır. Serum vaspin düzeyi ile koroner arter hastalığı arasında ilişki olup olmadığı henüz bilinmemektedir. Çalışmamızda, serum vaspin düzeylerinin koroner anjiografi yapılmış stabil anjina pektorisli hastalarda damar tutulum dereceleri ile ilişkisini araştırmayı amaçladık.

Yöntemler: Hastalar, stabil anjina pektoris tanısı ile koroner anjiografi yapılmış hastalar arasından seçildi. Bilinen kronik kalp hastalığı, kronik karaciğer hastalığı, böbrek yetmezliği, tiroit disfonksiyonu olan, immünsüpresif tedavi alan, herhangi bir sistemik enfeksiyöz veya malign hastalığı olanlar ile onam formu vermeyenler çalışmaya alınmadı. Serum vaspin ölçümleri sandviç enzim bağlı immün ölçüm (ELISA) metodu kullanarak east biopharm ELISA kiti ile yapıldı. Koroner lezyonların şiddeti modifiye Gensini skoru kullanılarak belirlendi.

Bulgular: Çalışmaya seksen sekiz hasta [34 kadın $(\% 38,6)$ ve 54 erkek $(\% 91,4)]$ dahil edildi. Vaspin düzeyleri erkeklerde $(1,17 \pm 1,54 \mathrm{ng} / \mathrm{L})$ ve kadınlarda $(1,09 \pm 1,23 \mathrm{ng} / \mathrm{L})$ benzerdi. $(p=0,46)$. Vaspin düzeyleri tutulan damar sayısı ile korele değildi $(p=0,75)$. Vaspin düzeyleri diyabetik ve diyabetik olmayan hastalarda benzer seviyelerde idi.

Sonuç: Vaspin, stabil anjina pektorisli hastalarda damar tutulum derecesi için hassas bir belirteç olmayabilir. Bunun nedeni dahil edilen grupta enflamatuvar kaskatta ve oksidatif streste belirgin değişim olmaması olabilir.

Anahtar Sözcükler: Vaspin, anjina pektoris, Gensini skoru

Keywords: Vaspin, angina pectoris, Gensini score

Address for Correspondence/Yazışma Adresi: Ilter Bozacı, Bozyaka Training and Research Hospital, Clinic of Nephrology, İzmir, Turkey

Phone: +90 23224050 50/2136 E-mail: ilterbozaci@gmail.com ORCID: orcid.org/0000-0001-7535-9403 Received/Geliş Tarihi: 08 January 2020 Accepted/Kabul Tarihi: 04 February 2020
Copyright 2020 by The Medical Bulletin of istanbul Haseki Training and Research Hospital The Medical Bulletin of Haseki published by Galenos Yayınevi. ${ }^{\top}$ Telif Hakkı 2020 istanbul Haseki Eğitim ve Araşıırma Hastanesi Haseki Tıp Bülteni, Galenos Yayınevi tarafindan yayınlanmıştı. 


\section{Introduction}

Atherosclerotic coronary artery disease is the leading cause of death in developed countries. The defined risk factors for cardiovascular diseases are positive family history, lipid metabolism disorders, advanced age, male gender, Diabetes Mellitus, insulin resistance and Metabolic syndrome, hypertension, sedentary life style, smoking, heavy alcohol use, elevated homocysteine, C-reactive protein (CRP) and fibrinogen levels and low estrogen levels (1-4). Interventions against these factors have led to significant improvements in morbidity and mortality in these patients.

Recent studies have revealed that adipose tissue had some endocrine functions besides being a fat store (5). Vaspin is an insulin-sensitive adipokine secreted from visceral fat tissue, and belongs to the serine protease inhibitor family (6). Serum vaspin level is positively correlated with obesity and insulin resistance $(7,8)$. Aust et al. (6) reported a correlation between low vaspin levels and ischemic events within the last three months in patients with carotid artery stenosis due to atherosclerosis; although there was no relationship between vaspin levels and data related with the severity of stenosis.

The relationship between vaspin level and coronary artery disease is not known yet. Vaspin level has been found to be low in patients with coronary artery disease in some of the studies while it was reported to be elevated in others. We aimed to investigate the relationship between serum vaspin levels and the degree of vessel involvement in coronary angiography in patients with stable angina pectoris.

\section{Methods}

\section{Patients}

Patients were chosen from those who had coronary angiography with the diagnosis of stable angina pectoris. The study was started after obtaining approval from the local ethics committee (decision no: 2011-714198). All patients provided written informed consent. Demographics and clinical data of the patients including age, gender, smoking history, past medical history (Diabetes Mellitus, hypertension, dyslipidemia), family history and the treatment schedule were recorded. Weight and height of the patients were recorded. Body Mass index (BMI) was calculated with the formula-BMl=weight $(\mathrm{kg}) /$ height $^{2}$ (meters).

\section{Exclusion Criteria}

Patients with a previous diagnosis of chronic heart disease (previous myocardial infarction and/or coronary artery by-pass surgery, prominent valvular heart disease), chronic liver disease, renal failure, thyroid dysfunction and any systemic infectious or malignant disease, patients receiving immunosupressive treatment and those who did not gave informed consent were excluded from the study.

For the determination of risk factors for coronary artery disease, the National Cholesterol Education Program Adult Treatment Panel III (NCEP-ATPI III), and the guideline for prevention and treatment of coronary artery disease published by the Turkish Society of Cardiology in 2002 were used $(9,10)$. With this guidance, risk factors were defined as follows:

Age $>45$ years in males and $>55$ years in females was regarded as advanced age. Postmenopausal women were accepted as at risk without considering age. According to the definitions by international guidelines, patients with a BMI of 25-29.9 were considered overweight, and those with a BMI of $\geq 30$ were regarded as obese (11). Positive family history was defined as a history of coronary artery disease in the first degree male relatives before the age of 55 , and in the first degree female relatives before the age of 65 years. Patients with a previous diagnosis of type 2 Diabetes Mellitus or fasting blood glucose level higher than $125 \mathrm{mg} / \mathrm{dL}$ were recorded as diabetic. Hypertension was defined as a blood pressure of more than 140/90 mmHg; or being on antihypertensive treatment. Patients with a low-density lipoprotein (LDL) cholesterol (or total cholesterol) and triglyceride level greater than $130 \mathrm{mg} / \mathrm{dL}$ (or $200 \mathrm{mg} / \mathrm{dL}$ ) and 150 $\mathrm{mg} / \mathrm{dL}$ were accepted as hypercholesterolemic and hypertriglyceridemic, respectively. $\mathrm{HDL}$ cholesterol levels were regarded as low if below $40 \mathrm{mg} / \mathrm{dL}$. Patients who smoke actively, or have been smoking until the last two years were accepted as smokers.

\section{Laboratory Analysis}

Blood samples were collected after 10-12 hours of fasting before coronary angiography for determination of creatinine, glucose, total cholesterol, HDL cholesterol, LDL cholesterol, triglyceride, high sensitive CRP (hsCRP), interleukin-6 (IL-6), reactive oxygen species (ROS), nitric oxide (NO) and vaspin levels. Serum samples were stored at $-20{ }^{\circ} \mathrm{C}$ until analysis. Serum vaspin and IL-6 measurements were performed by an East Biopharm ELISA kit using the sandwich enzyme-linked immunoassay (ELISA) method. The reference range was $0.05-10 \mathrm{ng} /$ $\mathrm{mL}$ for vaspin and 2-600 $\mathrm{ng} / \mathrm{L}$ for IL-6. Serum ROS and NO levels were measured by a cusabio ELISA kit using the sandwich ELISA method. The ranges were $0.16-10.00 \mathrm{ng} /$ $\mathrm{mL}$ and $0-20 \mathrm{ng} / \mathrm{mL}$ for ROS and NO, respectively. Hs-CRP levels were studied by the turbidimetric method using a Siemens Advia 2400 auto analyzer (normal limits: 0-5 mg/ $d L)$. 


\section{Angiography Technique}

After clinical and laboratory evaluation for risk factors, all patients had coronary angiography by the same operator. Coronary angiography was performed with the judkins technique after twelve hours of fasting. The right and left coronary arteries were viewed at multiple projections. The evaluation of angiographies and scoring of the lesions were performed by two operators.

\section{Calculation of the Gensini score}

For determination of the severity of coronary lesions, the modified Gensini score was used (11). The major parameters for this scoring system were the artery involved, the location and the degree of narrowing of the vessel. Coronary arteries were divided into 27 segments with each segment given scores between 0.5 and 5.0. Percentage of narrowing was scaled in the range of 2-64. Gensini score was obtained by multiplying these numbers. The patients were divided into two groups according to the degree of their vascular lesions in angiography.

Group 1: Those with lesions not causing critical stenosis in angiography and/or those with a Gensini score of less than 50 .

Group 2: Those with lesions causing critical stenosis in angiography and/or those with a Gensini score of more than 50 .

\section{Statistical Analysis}

Data were analyzed using the Statistical Package for Social Sciences (SPSS) for Windows 16.0. Numerical values were expressed as mean \pm standard deviation. For intergroup comparisons, the paired samples t-test and Mann-Whitney $U$ test were used when necessary. For nonnumeric values (gender, presence of diabetes mellitus, etc.), Fisher's exact test and Yates' chi-square test for $2 \times 2$ contingency tables were used when appropriate. Correlation analysis related with vaspin levels was performed with Spearman's rho, as vaspin had abnormal distribution. Linear regression analysis was used to determine factors affecting vaspin level. The dependent parameter was vaspin, while independent parameters were age, gender, the study group and hsCRP levels. A $p$ value of less than 0.05 was considered statistically significant.

\section{Results}

Eighty-eight patients [34 female (38.6\%) and 54 male $(91.4 \%)]$ were included in the study. The mean age was $61.2 \pm 9.8$ years (33-77). Smoking history was positive in 44 patients $(50 \%)$. The major comorbidities were hypertension ( $n=61 ; 69.3 \%)$, Diabetes Mellitus ( $n=36$; $40.9 \%)$ and hyperlipidemia ( $n=30 ; 34.1 \%)$. Thirty-four patients (38.6\%) had a family history of coronary artery disease.
The number of vessels involved was one in 21 patients (23.9\%), two in $20(22.7 \%)$, three in $13(14.8 \%)$ and none in 34 patients (38.6\%). The mean Gensini score was $43.67 \pm 51.01$ (0-268). The patients were grouped according to Gensini score as described before. There were 50 patients in (57\%) in group 1, and 38 patients $(43 \%)$ in group 2. Demographic data, comorbidities and laboratory results of the groups are presented in Table 1. The levels of the cytokines studied are presented in Table 1 and Figure 1.

Vaspin and IL-6 levels were similar in male $(1.17 \pm 1.54$ $\mathrm{ng} / \mathrm{L}$ and $151 \pm 276 \mathrm{ng} / \mathrm{L}$, respectively) and female $(1.09 \pm 1.23 \mathrm{ng} / \mathrm{L}$ and $119 \pm 251 \mathrm{ng} / \mathrm{L}$, respectively) patients $(p=0.46$ and $p=0.61$, respectively), while $N O$ level was significantly higher in female patients $(4220 \pm 2038 \mathrm{ng} / \mathrm{L}$ vs $3354 \pm 1762 \mathrm{ng} / \mathrm{L}, \mathrm{p}=0.024)$. ROS level was higher in female patients although the difference did not reach statistical significance $(0.43 \pm 0.26 \mathrm{ng} / \mathrm{L}$ vs $0.35 \pm 0.24 \mathrm{ng} / \mathrm{L}$, $\mathrm{p}=0.054)$. Vaspin, ROS, NOS, NO and IL-6 levels were not correlated with the number of vessels involved $(p=0.75$, $p=0.27, p=0.43$ and $p=0.52$, respectively). The patients were grouped according to the presence of Diabetes Mellitus and it was found that ROS level was significantly higher in the diabetic group $(0.45 \pm 0.30 \mathrm{ng} / \mathrm{L}$ vs $0.33 \pm 0.20$ $\mathrm{ng} / \mathrm{L}, \mathrm{p}=0.035)$, while vaspin, NO and IL-6 levels were similar in diabetic and nondiabetic patients.

\section{Discussion}

Cardiovascular diseases are the leading causes of death. Many risk factors have been recognized, and studies have been concentrated on early recognition and treatment of individuals with these risk factors. One of the most important risk factors is metabolic syndrome. Metabolic syndrome is the combination of obesity, cardiovascular diseases, type 2 Diabetes Mellitus, hypertension and hyperlipidemia (12). Metabolic syndrome is closely related with abdominal obesity (13). The imbalance between caloric intake and consumption causes hyperplasia and hypertrophy of the adipocytes and adipose tissue dysfunction (14). These processes lead to hyperlipidemia, elevated blood pressure, hypercoagulability and inflammation (15-17). Visceral adipose tissue has more important roles in production of proinflammatory cytokines and adipokines compared to other adipose tissues (18). One of these cytokines is vaspin which belongs to the serine protease inhibitor family and has insulin-sensitizing effects (19). Vaspin is produced by mature adipocytes, but is not expressed in stromal endothelial or vascular cells. Vaspin levels in the peripheral blood and in adipocytes have been found to be elevated in obese rats with insulin resistance (19). It was also found to be high in type 2 diabetics with or without obesity (20). 
Inflammation is thought to have roles in the development of atherosclerosis and its chronic complications $(1,21,22)$. Many studies have been performed to evaluate the relationship between atherosclerotic coronary artery disease and inflammation. Many bioactive substances, including vaspin, adiponectin, leptin, tumor necrosis factoralpha, plasminogen activator inhibitor-1, interleukin-6, resistin and various growth factors, that are synthesized and secreted to the circulation by visceral adipose tissue have been defined recently. They were shown to have local and endocrine roles in the development of atherosclerosis (23-25). They are claimed to be responsible for early and accelerated atherosclerosis in obese individuals (26). The relationship between vaspin and coronary artery disease has not been evaluated yet. Inflammation is known to play a role in the development and progression of atherosclerosis, but the biochemical and cellular mechanisms have not been fully elucidated (27).

This study designed to investigate the relationship between serum vaspin levels and the degree of vessel involvement in coronary angiography in patients with stable angina pectoris.

It was performed in patients with stable angina pectoris who had mild (group 1) or severe (group 2) lesions in coronary angiography. Patients with a history of more severe cardiac disease (previous myocardial
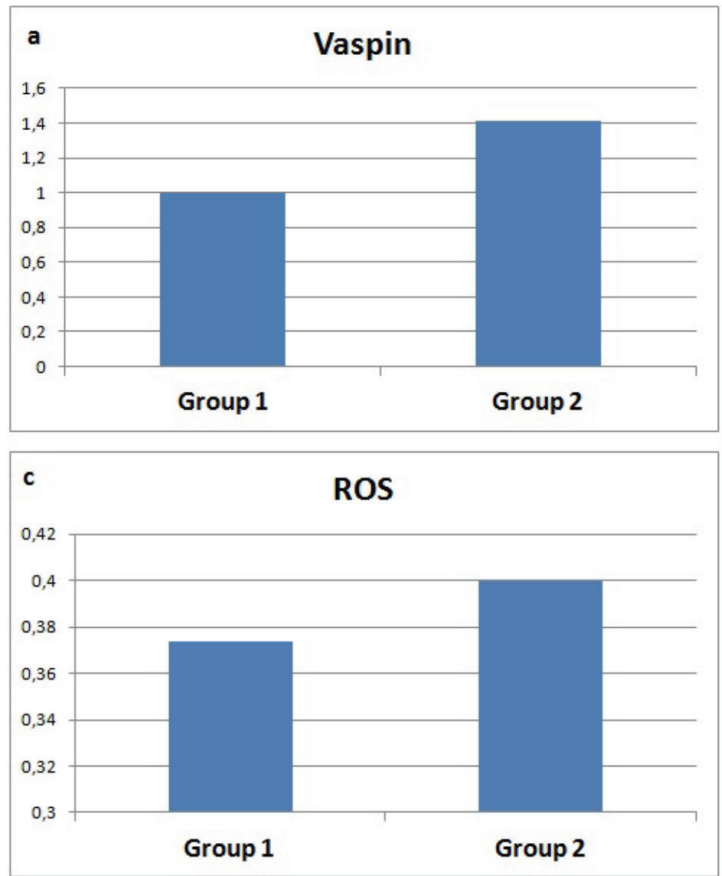

Figure 1. The comparison of the cytokine levels between groups NO: Nitric oxide, ROS: Reactive oxygen species, IL-6: Interleukin infarction and/or coronary artery bypass surgery, prominent valvular heart disease) were not included in the study. The mean Gensini score was 43.67 \pm 51.01 (0-268). Hypertension ( $n=61,69.3 \%)$, Diabetes Mellitus ( $n=36$, $40.9 \%)$ and hyperlipidemia ( $n=30,34.1 \%)$ were the major comorbidities. Thirty-four patients (38.6\%) had a family history of coronary artery disease, and 44 patients (50.0\%) were smokers. Comparison of the groups regarding demographic and biochemical parameters yielded a higher frequency of female gender and smoking history in group 1 (Table 1).

Vaspin and IL-6 levels were similar in both genders, while NO and ROS levels were higher in women although only the difference regarding ROS level reached statistical significance. There was no correlation of the number of involved vessels with vaspin, ROS, NO and IL-6 levels. Vaspin, IL-6 and NO levels in diabetic and non-diabetic patients were similar. Thus, there was no correlation between the severity and the number of coronary arteries involved and markers of inflammation and oxidative stress. This fact may be due to patient selection criteria. Besides, diabetes mellitus was not a factor affecting vaspin levels.

Kadoglou et al. (28) reported lower vaspin levels in patients with coronary artery disease compared to healthy individuals. In their study including 40 patients with stable angina pectoris without Diabetes Mellitus, morbid obesity, history of coronary artery disease and/or coronary revascularization and 40 healthy controls, Kobat
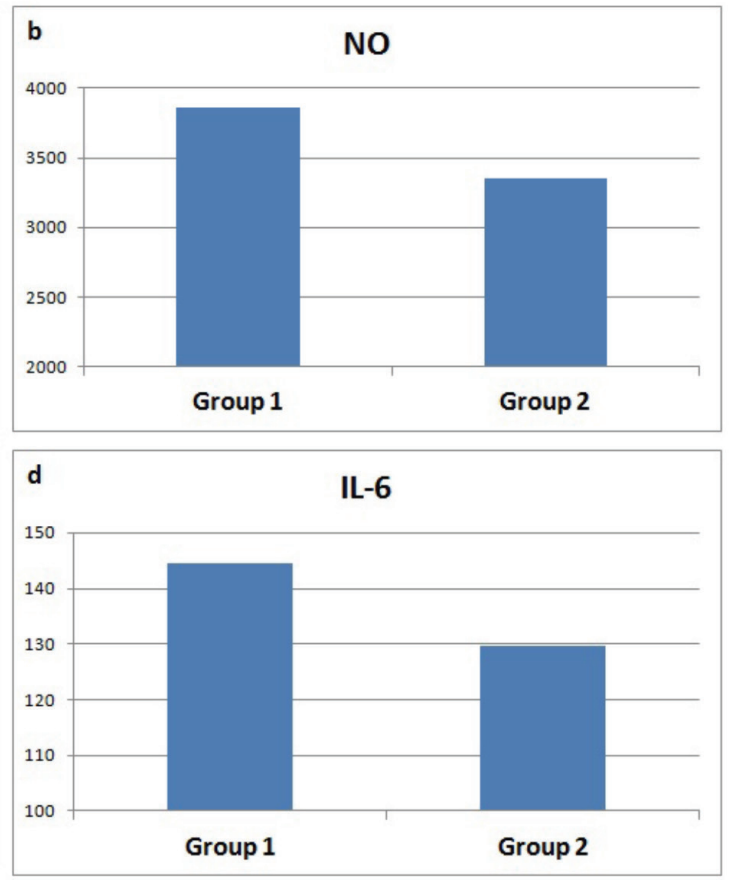
et al. (29) found that the mean vaspin level in the patient group was significantly lower than in the control group. Zhang et al. (30) reported the lowest values of vaspin in patients with acute myocardial infarction followed by in those with unstable angina pectoris, stable angina pectoris and no coronary artery disease, in ascending order. Aust et al. (6) evaluated serum vaspin concentrations in patients with carotid stenosis who underwent carotid endarterectomy. They reported that vaspin level was not correlated with the severity of carotid lesions, but vaspin level was significantly lower in patients with carotid artery stenosis with a history of ischemic stroke within the last three months. They detected no difference in vaspin levels before and after endarterectomy.

There is no clear explanation for different data in the literature including the presented study. However, it can be said that it is difficult to evaluate vaspin level in all patients with coronary artery disease. Besides, there are many factors that may interfere with vaspin levels including obesity, Diabetes Mellitus and many pharmacological and non-pharmacological factors affecting levels of both cytokines and adipokines. Weight loss, exercise, thiazolidinediones, metformin, salicylates, angiotensin II receptor blockers, angiotensin converting enzyme inhibitors, statins, fibrates and beta blockers are among other factors affecting vaspin level $(31,32)$.

The other important finding in the presented study is the similar vaspin levels in patients with and without diabetes mellitus $(0.80 \pm 0.41 \mathrm{ng} / \mathrm{L}$ vs $1.38 \pm 1.80 \mathrm{ng} / \mathrm{L}$, $p=0.03)$. It has been reported that vaspin level decreased in the presence of diabetic microvascular complications, although the issue is not clear because the proteases acting on vaspin release in diabetes mellitus have not been elucidated yet (32). On the other hand, vaspin level increases as the Hemoglobin A1c (HbA1c) level rises, possibly due to compensatory effect of vaspin (33). Thus, change in vaspin level may be regarded as a factor associated with chronic vascular disease besides its relationship with metabolic and vascular changes.

\section{Study Limitations}

The major limitation of our study is lack of patients with more severe coronary artery disease. Inclusion of another group composed of patients with unstable angina pectoris or myocardial infarction would more clearly delineate differences in vaspin levels and the role of other markers. Moreover, availability of data regarding medications given to study participants would allow more

\begin{tabular}{|c|c|c|c|c|c|c|c|}
\hline & \multicolumn{3}{|l|}{$\begin{array}{l}\text { Group } 1 \\
(n=58)\end{array}$} & \multicolumn{3}{|l|}{$\begin{array}{l}\text { Group } 2 \\
(n=30)\end{array}$} & \multirow[t]{2}{*}{ p } \\
\hline & Mean & Min & Max & Mean & Min & Max & \\
\hline Age & $59.8 \pm 10.1$ & 33.0 & 77.0 & $63.7 \pm 8.8$ & 47.0 & 77.0 & 0.077 \\
\hline Gender (F/M) & \multicolumn{3}{|l|}{$30 / 28$} & \multicolumn{3}{|l|}{$4 / 26$} & $<0.001$ \\
\hline Family history (\%) & \multicolumn{3}{|l|}{43.1} & \multicolumn{3}{|l|}{30.0} & 0.23 \\
\hline Smoking (\%) & \multicolumn{3}{|l|}{55.2} & \multicolumn{3}{|l|}{40.2} & $<0.001$ \\
\hline DM (\%) & \multicolumn{3}{|l|}{43.1} & \multicolumn{3}{|l|}{36.7} & 0.56 \\
\hline HT (\%) & \multicolumn{3}{|l|}{70.7} & \multicolumn{3}{|l|}{66.7} & 0.70 \\
\hline Hyperlipidemia (\%) & \multicolumn{3}{|l|}{31.0} & \multicolumn{3}{|l|}{40.0} & 0.40 \\
\hline BMI $\left(\mathrm{kg} / \mathrm{m}^{2}\right)$ & $29.5 \pm 5.6$ & 17.9 & 45.0 & $28.6 \pm 3.3$ & 22.9 & 36.3 & 0.42 \\
\hline Glucose (mg/dL) & $123 \pm 49$ & 80 & 419 & $121 \pm 45$ & 77 & 265 & 0.865 \\
\hline $\mathrm{HDL}(\mathrm{mg} / \mathrm{dL})$ & $45 \pm 14$ & 27 & 86 & $44 \pm 10$ & 23 & 64 & 0.645 \\
\hline hsCRP (mg/dL) & $2.43 \pm 1.90$ & 0.10 & 9.40 & $2.71 \pm 2.1$ & 0.10 & 6.80 & 0.52 \\
\hline Creatinine $(\mathrm{mg} / \mathrm{dL})$ & $0.95 \pm 0.14$ & 0.60 & 1.40 & $0.96 \pm 0.19$ & 0.21 & 1.40 & 0.88 \\
\hline LDL (mg/dl) & $121 \pm 33$ & 43 & 194 & $130 \pm 43$ & 64 & 238 & 0.31 \\
\hline Leukocyte $\left(10^{3} / \mathrm{mm}^{3}\right)$ & $6.82 \pm 1.26$ & 4.58 & 9.80 & $7.30 \pm 1.5$ & 4.80 & 10.60 & 0.118 \\
\hline IL6 (ng/L) & $144 \pm 282$ & 3 & 1331 & $129 \pm 238$ & 15 & 1098 & 0.814 \\
\hline Vaspin (ng/L) & $0.99 \pm 1.03$ & 0.49 & 6.29 & $1.41 \pm 1.97$ & 0.51 & 8.21 & 0.19 \\
\hline NO (ng/L) & $3861 \pm 2043$ & 858 & 11049 & $3357 \pm 1602$ & 1248 & 7864 & 0.243 \\
\hline $\operatorname{ROS}(\mathrm{ng} / \mathrm{L})$ & $0.37 \pm 0.23$ & 0.06 & 1.49 & $0.40 \pm 0.3$ & 0.06 & 1.22 & 0.654 \\
\hline
\end{tabular}


precise comparison. Inclusion of $\mathrm{HbA} 1 \mathrm{c}$ in the statistical analysis would reveal another relationship.

\section{Conclusion}

Vaspin may not be a sensitive marker of the degree of vascular lesions in patients with stable angina pectoris. The underlying cause is probably lack of significant changes in inflammatory cascade and oxidative stress in the involved group of patients. Further controlled studies in diabetic and non-diabetic patients with more severe coronary artery disease are warranted.

\section{Authorship Contributions}

Concept: I.B., S.Ö., A.A.Ö., M.K., O.Ö. Design: S.Ö., O.Ö., I.B., A.A.Ö. Data Collection or Processing: I.B., S.Ö., A.A.Ö., M.K. Analysis or Interpretation: S.Ö., I.B., M.K. Literature Search: I.B., O.Ö. Writing: I.B.

Conflict of Interest: No conflict of interest was declared by the authors.

Financial Disclosure: The authors declared that this study received no financial support.

\section{References}

1. Geovanini GR, Libby P. Atherosclerosis and Inflammation. Overview and Updates.Clin Sci (Lond) 2018;132:1243-52.

2. Strain WD,Paldanius PM.Diabetes, cardiovascular disease and Microcirculation. Cardiovasc Diabetol 2018;17:57.

3. Koenig W. C-Reactive Protein and Cardiovascular Risk: Will the Controversy End After CANTOS.Clin Chem 2017;63:1897-8.

4. Ganguly P,Alam SF.Role of Homocysteine in the Development of Cardiovascular Disease.Nutr J 2015;14:6.

5. Hida K, Wada J, Eguchi J, et al. Visceral adipose tissuederived serine protease inhibitor: a unique insulinsensitizing adipocytokine in obesity. Proc Natl Acad Sci USA 2005;102:10610-5.

6. Aust $\mathrm{G}$, Richter $\mathrm{O}$, Rohm S, et al. Vaspin serum consantrations in patients with carotid stenosis. Aterosclerosis 2008;204:262-6.

7. Shaker OG, Sadik NA. Vaspin gene in rat adipose tissue:relation to obesity-iduced insulin resistance.Moll Cell Biochem 2013;373:229-39.

8. Chang HM, Lee HJ, Park HS, et al. Effects of weight reduction on serum vaspin concentrations in obese subjects:modification by insulin resistance. Obesity (Silver Spring) 2010;18:2105-10.

9. Lane DM. Third Report of the National Cholesterol Education Program (NCEP.III): A Switch From Dietary Modification to Risk Factor Assessment. Curr Opin Investig Drugs 2001;2:1235-6.

10. Mahley RW, Pepin GM, Bersot TP, Palaoglu KE, Ozer K. Türk Kalp Çalışmasında Yeni Sonuçlar.Plazma Lipidleri ve Yüksek Yoğunluklu Lipoprotein Düzeyleri Düşüklüğünde Tedavi için Rehber Öneriler.Türk Kardiyoloji Derneği Araş 2002;30:93103.
11. Yumuk V, Tsigos J, Fried $M$, et al. European Guidelines for Obesity Managements in Adults.Obese Facts 2015;8:402-24.

12. Grundy Scott M, Cleeman James I, Daniels Stephen R, et al. Diagnosis and The Management of Metabolic Syndrome Circulation 2005;112:2735-52.

13. Lind L, Amlov J, Lampa E. The Interplay Between Fat Mass and Fat Distribution as Determinants of the Metabolic Syndrome is Sex-Dependant.Metab Syndr Relat Disord 2017;15:337-43.

14. Longo M, Zatterale F, Naderi J, et al. Adipose Tissues Dysfuction as Determinant of Obesity-Associated Metabolic Complications. Int J Mol Sci 2019;20.pii:E2358

15. Hosseini-Esfahani F, Bahadoran Z, Moslehi N, et al. Metabolic Syndrome: Findings from 20 Years of The Tehran Lipid and Glucose Study.Int J Endocrinol Metab 2018;16(4 Suppl):e84771.

16. Patel A, Thompson A, Abdelmalek L, Adams-Huet B, Jialal I. The Relationship Between Tyramine Levels and Inflammation in Metabolic Syndrome. Horm Mol Biol Clin Investig 2019;40:pii.

17. Zahran AM, Sayed SK, Abd El Hafeez HA, Khalifa WA, Mohammed NA, Hetta HFCirculating Microparticle Subpopulation in Metabolic Syndrome:Relation to Oxidative Stress and Coagulation Markers. Diabetes Metab Syndr Obes 2019;12:485-93.

18. Sulaieva O,Chereshneva Y,Kartashkina N, Ivanova M,Tsomartova D. Secretory Function of White Adipose Tissue and Adipokines:Biological Effects and Clinical Significance(Review). Georgian Med News 2018;274:116-24.

19. Gao FF, Liu GG, Zheng RX, Jiang LH,Bao PL. Correlation Between Vaspin Concentration and Insulin Sensitivity in the Visceral Adipose Tissue of Young Obese Rats.Zhongguo Dang Dai Er Ke Za Zhi 2013;15:71-4.

20. Feng R,Li Y,Wang C,Luo C,Liu L,Chuo F,Li Q,Sun C.Higher Vaspin Levels in Subjects with Obesity and Type-2 Diabetes Mellitus:a Metaanalysis.Diabetes Res Clin Pract 2014;106:8894.

21. Pant S, Deshmukh A,Gurumurthy GS,Pothineni NV,Watts TE,Romeo F,Mehta JL.Inflammation and AtherosclerosisRevisited.J Cardiovasc Pharmacol Ther 2014;19:170-8.

22. Kavurma MM, Rayner KJ, Karunakaran D. The walking Dead:Macrophage Inflammation and Death in Atherosclerosis. Curr Opin Lipidol 2017;28:91-8.

23. Dimova R,Tankova T. The Role of Vaspin in the Development of Metabolic and Glucose Tolerance Disorders and Atherosclerosis.Biomed Res Int 2015;2015:823481.

24. Cinar N, Gurlek A. Association Between Novel Adipocytokines Adiponectin, Vaspin, Visfatin and Throid.An Experimental and Clinical Update. Endocr Connect 2013;2:R30-8.

25. Park HK, Kwak MK, Kim HJ, Ahima RS. Linking Resistin, Inflammation and Cardiometabolic Diseases.Korean J Intern Med 2017;32:239-47. 
26. Smekal A, Vaclavik J.Adipokines and Cardiovascular Disease:A Comprehensive Review.Biomed Pap Med Fac Univ Palacky Olomouc Czech Repub 2017;161:31-40.

27. Taleb S.Inflammation in Atherosclerosis.Arch Cardiovasc Dis.2016 Dec;109:708-15.

28. Kadoglou NP, Gkontopoulos A, Kapelouzou A, et al. Serum levels of vaspin and visfatin in patients with coronary artery disease-Kozani study. Clin Chim Acta 2011;412:48-52.

29. Kobat MA, Celik A, Balin M, et al. The Investigation of Serum Vaspin Level in Atherosclerotic Coronary Artery Disease. J Clin Med Res 2012;4:110-3.

30. Zhang B, Peng W, Wang K, Li H, Xu Y. Vaspin as a Prognostic Marker in Patients with Acute Myocardial Infarction. Heart Lung Circ 2016;25:257-64.
31. Kadoglu NP, Vrabas IS, Kapelouzou A, et al. Impact of Atorvastatin on Serum Vaspin Levels in Hypercholesterolemic Patients with Moderate Cardiovascular Risk. Regul Pept 2011;170:57-61.

32. Kadoglu NP, Kapelouzou A, Tsanikidis H, Vitta I, Liapis CD, Sailer N. Effects of Rosiglitazone/Metformin Fixed-Dose Combination Therapy and Metformin Monotheraphy on Serum Vaspin,Adiponectin and IL-6 Levels in Drug Naïve Patients with Type-2 Diabetes. Exp Clin Endocrinol Diabetes 2011;119:63-8

33. Yang $W$, Li $Y$, Tian $T$, Wang $L$, Lee $P$, Hua Q. Serum Vaspin Concentration in Elderly Patients with Type 2 Diabetes Mellitus and Macrovascular Complications.BMC Endocr Disord 2017;17:67. 